\title{
Review of the tribe Typoderini (Coleoptera: Curculionidae) from Caucasus with the description of a new species of Caulomorphus from Armenia
}

\author{
Peter HLAVÁČ \\ Department of Entomology, National Museum, Cirkusová 1740, CZ-193 00 Praha 9 - Horní Počernice, Czech Republic; \\ e-mail: peterhlavac@gmail.com
}

\author{
Accepted: \\ $23^{\text {rd }}$ November 2020 \\ Published online: \\ $4^{\text {th }}$ December 2020
}

\begin{abstract}
All genera of the tribe Typoderini presented in the Caucasus Region, i.e. Adexius Schönherr, 1834 (which is here transferred to Typoderini from Molytini based on morphological characters), Anchonidium Bedel, 1884, Aparopion Hampe, 1861, Caulomorphus Faust, 1886, and Pseudaparopion Borovec, Osella \& Zuppa, 2002, are diagnosed and partly illustrated. One new species, Caulomorphus kociani sp. nov., is described; Caulomorphus besucheti Osella, 1970, Caulomorphus talyschensis Reitter, 1897, and Anchonidium perpensum Faust, 1886 are redescribed. Lectotype is designated for Anchonidium perpensum. Keys to Caucasian genera of Typoderini and to all species of Caucasian Anchonidium and Caulomorphus are provided. A complete list of species with their distribution is given.
\end{abstract}

Key words. Coleoptera, Curculionidae, Molytinae, lectotype designation, new species, redescription, Caucasus, Palaearctic Region

Zoobank: http://zoobank.org/urn:1sid:zoobank.org:pub:18120C01-DAD7-4546-8802-EA8DA35679D9

(C) 2020 The Authors. This work is licensed under the Creative Commons Attribution-NonCommercial-NoDerivs 3.0 Licence.

\section{Introduction}

The tribe Typoderini belongs to the large and certainly polyphyletic subfamily Molytinae of the family Curculionidae. Molytinae (Cryptorhynchinae excluded, see RIEDEL et al. 2016) currently consist of 35 tribes (ALONSO-ZARAZAGA \& Lyal 1999, Alonso-ZarazaGa et al. 2017); the majority of them are poorly defined and their monophyly has never been properly tested. The first attempt based on three genes and a very limited number of taxa did not give any applicable result (GREBENNIKOv 2017). The validity of tribes is also questionable as genera are often transferred among them (Alonso-ZaraZaga \& Lyal 1999, AlonsoZARAZAGa 2013, Alonso-ZaraZaga et al. 2017) without providing clear evidence of the necessity of such acts.

A recent study of Cryptorhynchinae (RIEDEL et al. 2016) has shown that Cryptorhynchinae are monophyletic and have been excluded from Molytinae, a statement not accepted in the most recent catalogue of the Palaearctic Curculionoidea (Alonso-ZaraZaGA et al. 2017). Cryptorhynchinae are not treated as a part of Molytinae in this paper.

The subfamily Molytinae according to Alonso-ZA-
RAZAGA et al. (2017), excluding Cryptorhynchinae, are represented in the Palaearctic Region by 88 genera and 689 species and subspecies; only 38 genera with 327 species and subspecies are present in the western part of the Palaearctic Region (AlONSO-ZARAZAGA 2017).

Typoderini is a small Palaearctic, Oriental and Afrotropical tribe (the assignment of the genus Plessisellus Hoffmann, 1964 from Vanuatu to this tribe needs further verification) of flightless, litter-dwelling or subterranean small weevils (AlONSO-ZARAZAGA \& LYAL 1999, LYAL 2014). All members of the tribe are externally very similar, morphologically there are only weak diagnostic characters which support the existence of the tribe in its current composition; however, the monophyly of the tribe is very doubtful (GREBENNIKov 2017).

The Caucasus Region, as used here, covers the southern territory of European Russia, Georgia, Armenia, Azerbaijan, eastern Turkish provinces Rize, Artvin, Ardahan, Kars and Igdir, and finally West Azerbaijan of Iran. The fauna of Molytinae of this region is composed of 16 genera and 99 species (including a new species of Caulomorphus 
described in this paper) while the genus Plinthus Germar, 1817 with 58 described species is by far the most dominant genus. Adjacent Turkey has 14 genera and 95 species and subspecies of Molytinae. The tribe Typoderini is represented in the Caucasus Region by five genera and twelve species, as reviewed in this paper.

The aim of this paper is to provide a diagnosis and key of all genera of Typoderini of the Caucasus Region, to designate a lectotype for the problematic species Anchonidium perpensum Faust, 1886, to describe a new species of the genus Caulomorphus from Armenia, and to provide new records and redescribe some other species of this genus.

\section{Material and methods}

The adult specimens were examined with a Leica S8APO stereomicroscope with diffuse lighting at magnifications up to $128 \times$. Dry mounted specimens were relaxed in warm water and dissected. Male and female terminalia were macerated in $\mathrm{KOH}$ solution, embedded in Euparal and illustrated. All dissected parts were mounted on plastic labels and pinned together with the respective specimen. Illustrated structures were studied using a ZEISS stereoscopic microscope and figured using a camera lucida. The terminology of the rostrum and the genitalia follows OBERPRIELER et al. (2014). The head length was measured from the anterior margin of pronotum (base of head) to the anterior margin of the rostrum; the head width was measured across the eyes; the length of pronotum (PL) and the length of head (HL) was measured in midline, the elytral length (EL) was measured along the suture; the width refers to the maximum width of pronotum (PW) and elytra (EW). The body length is a combined length of the head, pronotum and elytra, measured separately.

The distribution of each species follows the Cooperative catalogue of Palaearctic Coleoptera Curculionoidea (Alonso-Zarazaga et al. 2017).

Label data are cited verbatim. Slash '/ separates different labels, (p) denotes printed labels, (h) denotes handwritten labels. All type specimens were provided with the following red printed label: HOLOTYPE, PARATYPE or LECTOTYPE, genus and species name of the respective taxon, P. Hlaváč det. or des., 2019.

The material is deposited in the following collections:

BMNH The Natural History Museum, London, United Kingdom (Max Barclay, Michael Geiser);

CJKH Jiří Krátký’s private collection, Hradec Králové, Czech Republic;

CJPH Jan Pelikán’s private collection, Hradec Králové, Czech Republic;

CLFC Luca Fancello's private collection, Cagliari, Italy;

CPHP Peter Hlaváč's private collection, Prague, Czech Republic;

NMPC National Museum, Prague, Czech Republic;

OUMNH Hope Entomological Collections, Oxford University, Oxford, United Kingdom (Amoret Spooner);

SMNS Staatliches Museum für Naturkunde, Stuttgart, Germany (Wolfgang Schawaller);

SMTD Museum für Tierkunde, part of Staatliche Naturhistorische Sammlungen Dresden, Germany (Olaf Jaeger);

ZMHB Museum für Naturkunde der Humboldt-Universität, Berlin (Joachim Willers, Bernd Jaeger).

\section{Results}

Typoderini

Typoderina Voss, 1965: 343 (as a subtribe of Liparini Latreille, 1828). Typoderina: Alonso-Zarazaga \& Lyal (1999): 196 (catalogue; as a subtribe of Molytini Schönherr, 1823).

Typoderini: Lyal (2014): 552 (diagnosis); Alonso-Zarazaga (2013): 496 (catalogue); Alonso-ZARAZAGA (2017): 490 (catalogue).

Anchonidium-group: ZHERICHIN (1987): 38 (diagnosis).

Diagnosis. Body length usually below $10 \mathrm{~mm}$ (less than $6 \mathrm{~mm}$ for west Palaearctic taxa). Eyes variable in size, from large (Adexius Schönherr, 1834, Pseudaparopion Borovec, Osella \& Zuppa, 2002), smaller (Anchonidium Bedel, 1884), reduced to single ommatidium (Caulomorphus Faust, 1886) or completely absent (cavernicolous genera Baezia Alonso-Zarazaga \& García, 1999 and Oromia Alonso-Zarazaga, 1987). If eyes present, they are positioned on head capsule at base of rostrum. Head sculptured, with strong punctation, sometimes with carinae, strongly and deeply retracted into prothorax so that anterior margin of prothorax seems much wider than visible part of head. Rostrum not separated from head capsule by transverse constriction or furrow, curved downwards, scrobe visible dorsally. Antennae inserted near apex of rostrum, scape pedunculate, reaching or not reaching anterior margin of eyes, funicule with 5-7 antennomeres, club well-defined, well-separated from funicule, its basal antennomere long, considerably longer than two following ones.

Sexual dimorphism. All studied genera have clear sexual dimorphism on all tibiae (Figs $3 \mathrm{a}-\mathrm{f}$ ). In males tibiae are simple, with sharp uncus, lacking premucro while in females in front of uncus there is always well-defined premucro. Ventrites 1 and 2 in males shallowly depressed.

Distribution. The centres of the diversity of the tribe are in the western part of the Palaearctic Region, especially in Turkey, Caucasus, the Near East, and in the Afrotropical Region, where many species are waiting for description, especially in mountain regions, especially in Cameroon, Democratic Republic of the Congo, Kenya, Tanzania and South Africa. The tribe is also present in China and Japan but so far unrecorded in the New World and Australia.

Biology. Members of the tribe as currently defined are edaphic or subterranean weevils, some known only from caves, but the majority of the genera are typical litter dwellers in well-protected temperate, subtropical or tropical deciduous forests.

\section{Key to genera of Typoderini in the Caucasus Region}

1 Elytra oval, EL/EW ratio $\leq 1.25$.................................... 2

- Elytra elongate, parallel-sided, at most slightly rounded in posterior half, EL/EW ratio $\geq 1.40$. .................. 3

2 Rostrum lacking carinae, antennae slender, all funicular antennomeres longer than wide, elytral striae granulate, elytra with fine and short setae, tegmen of aedeagus simple without parameres.

.... Pseudaparopion Borovec, Zuppa \& Osella, 2002

- Rostrum carinate, antennae stouter, at least some funicular antennomeres quadrate or transverse, elytral 

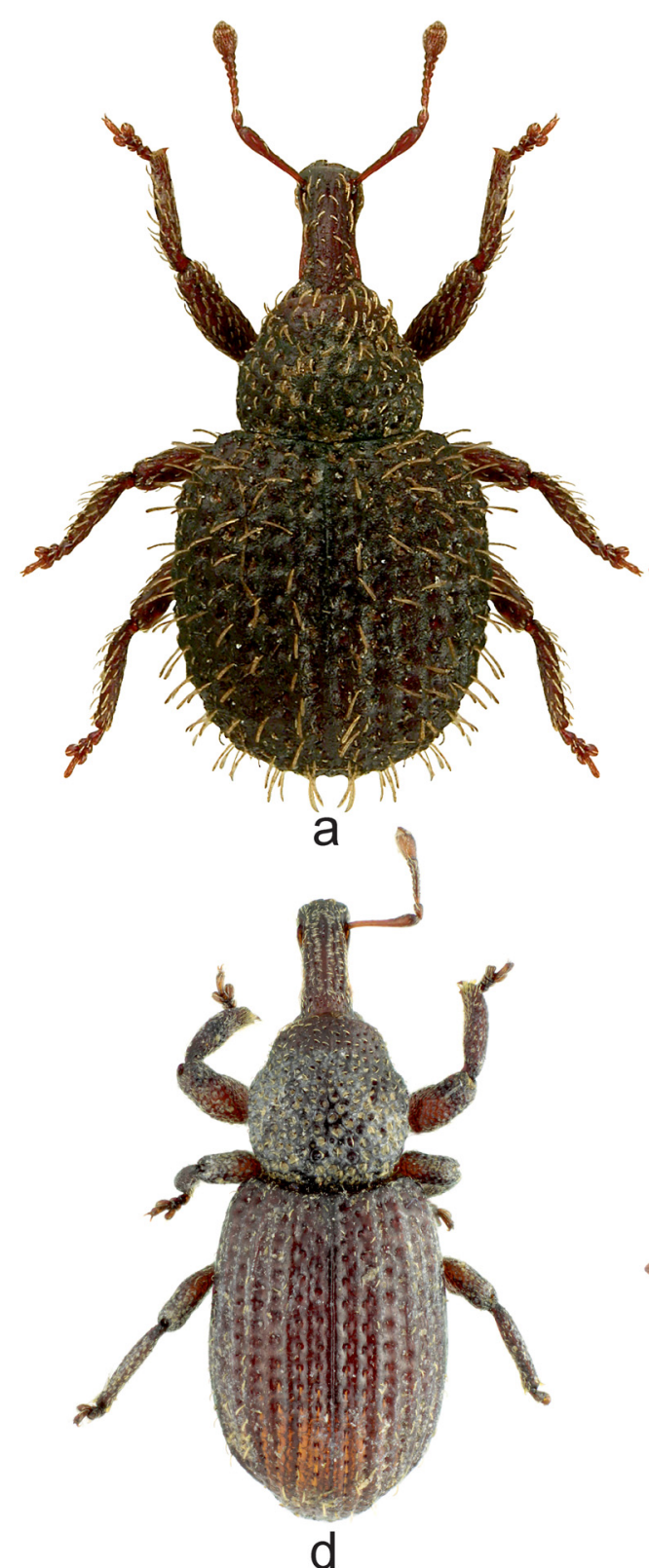

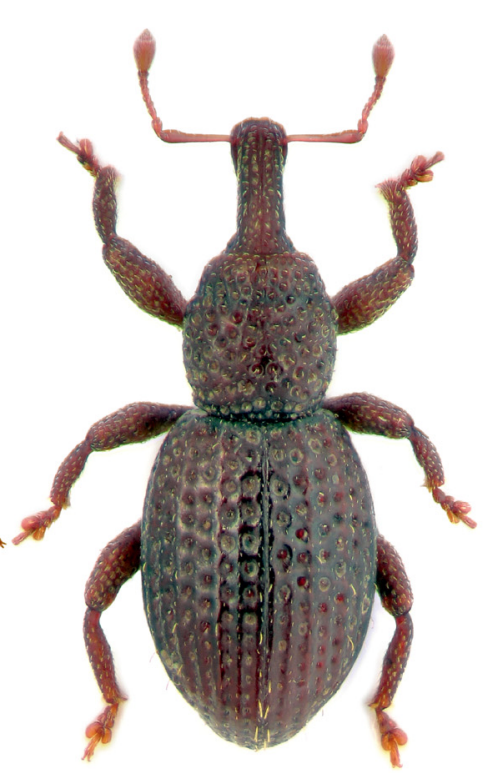

b

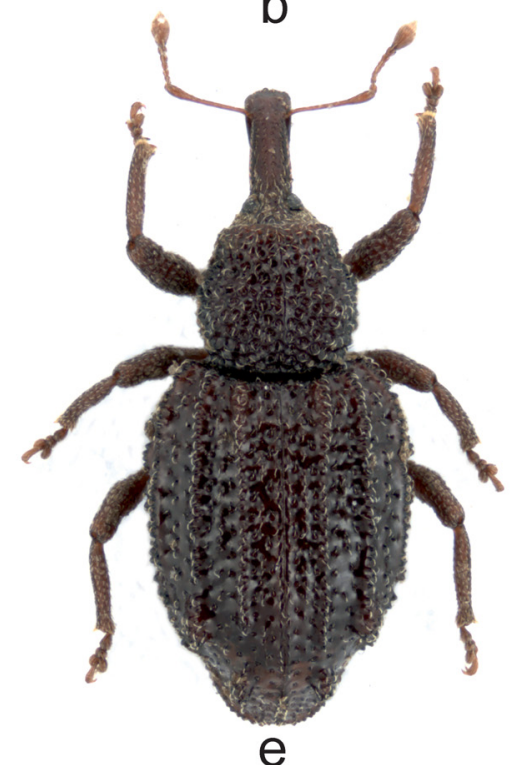

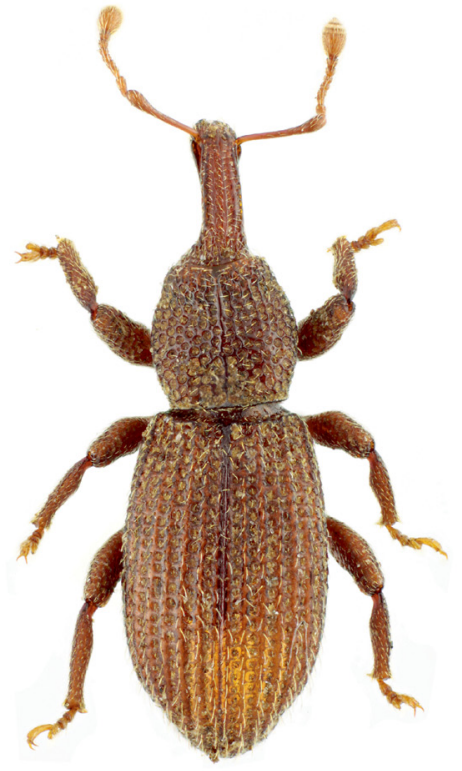



Fig. 1. Dorsal habitus. a - Adexius scrobipennis Gyllenhal, 1834; b - Anchonidium caucasicum Motschulsky, 1845; c - Caulomorphus kociani sp. nov.; d-Anchonidium perpensum Faust, 1886; e - Aparopion costatum (Fåhraeus, 1843); f - Pseudaparopion kadleci Borovec, Osella \& Zuppa, 2002.

striae with large punctures, elytra with erect setae, tegmen of aedeagus with well-defined parameres.

Adexius Schönherr, 1834

3 Eyes reduced to single ommatidium, apex of median lobe of aedeagus with a few short setae.

Caulomorphus Faust, 1886

- Eyes present, apex of median lobe lacking setae. ....... 4

4 Rostrum carinate, elytra lacking tubercles, antennomere II more than $1.5 \times$ as long as III, head shorter than pronotum, median lobe of aedeagus dorsally symmetrical.

Anchonidium Bedel, 1884

- Rostrum lacking carinae, elytra with tubercles, antennomere II about as long as III, head longer than pronotum, median lobe of aedeagus dorsally asymmetrical.

Aparopion Hampe, 1861

\section{Adexius Schönherr, 1834}

(Figs 1a, 2a-e, 3a-h)

Adexius Schönherr, 1834: 366 (original description). ReITTER (1913): 53 (key); Alonso-Zarazaga \& Lyal (1999): 195 (catalogue); AlonSO-ZARAZAGA (2013): 488 (catalogue); Alonso-ZaraZAGa (2017): 480 (catalogue).

Type species. Adexius scrobipennis Gyllenhal, 1834 by original designation.

Diagnosis. Body oval (Fig. 1a), length 2.2-3.2 mm, elytra and pronotum with erect, sparse setae on whole surface, head shorter than pronotum. Eyes large, oval, clearly visible in dorsal view, situated at base of rostrum and on head. Rostrum carinate, densely punctate, scrobes visible dorsally. Antennae stout, scape short, not reaching anterior margin of eyes, funicule with 7 antennomeres 


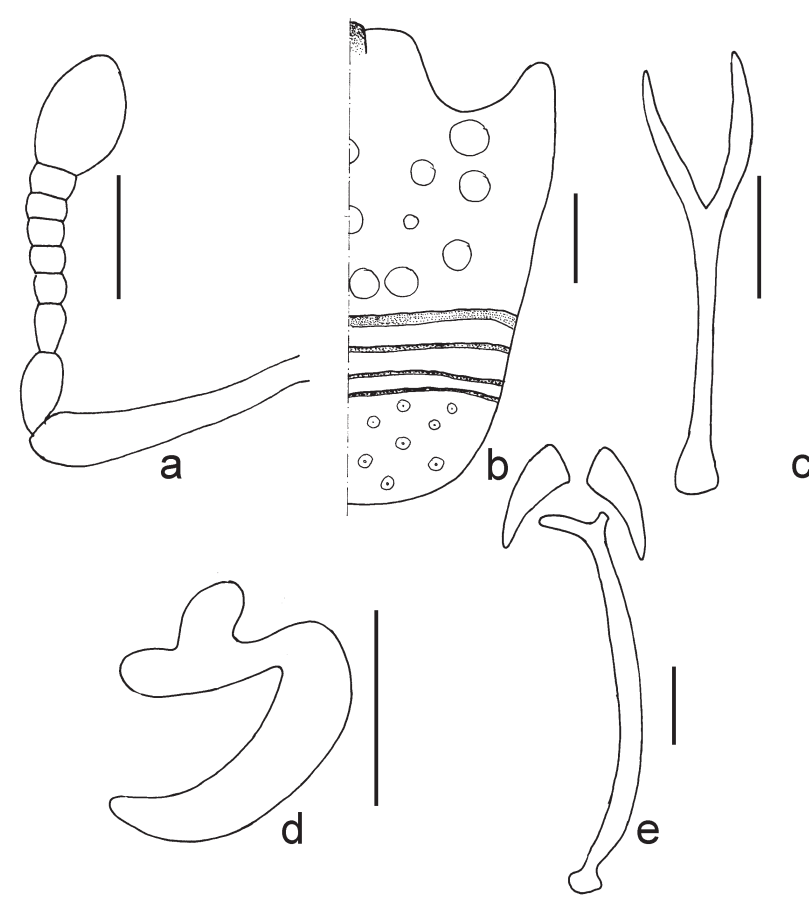

Fig. 2. Adexius scrobipennis Gyllenhal, 1834: a - antenna; b - abdominal ventrites I-V; c - sternite VIII; d - spermatheca; e - sternite IX and hemisternites. Scale bars: $0.2 \mathrm{~mm}$.



Fig. 3. Adexius scrobipennis Gyllenhal, 1834: a - left foreleg, male; $\mathrm{b}$ - left midleg, male; c - left hindleg, male; $\mathrm{d}$ - left foreleg, female; e left midleg, female; $\mathrm{f}$ - left hindleg, female; $\mathrm{g}$ - aedeagus, dorsal view; $\mathrm{h}$ - aedeagus, lateral view. Scale bars: $0.2 \mathrm{~mm}$.

(Fig. 2a), antennomeres II and III of about same length. Pronotum lacking carinae or smooth median line, rugosely punctate, constricted before apex, postocular lobe absent, scutellum not visible. Elytra wide, EL/EW ratio $<1.25$, interstriae flat, striae with large punctures, apex of elytron rounded. Procoxae contiguous, mesocoxae widely separated, ventrite I and II separated by suture, ventrite I considerably longer than II (Fig. 2b). Legs stout (Figs 3a-c male, 3d-f female), tarsomere III strongly bilobed, onychium short, less than twice as long as tarsomeres II and III combined. Male terminalia: median lobe of aedeagus (Figs 3g-h) symmetrical, lacking internal sclerites, parameres well-developed, male sternite IX (Fig. 2e), hemisternite slender, subtriangular. Female terminalia: spermatheca (Fig. 2d), sternite VIII cradle-like (Fig. 2c). Remarks. Adexius is a monotypic genus, currently classified in the tribe Molytini, subtribe Plinthina. The genus is here transferred to Typoderini based on the general appearance, the position of eyes and similar sexual dimorphism of tibiae. All reports of Adexius corcyreus Reitter, 1884 from Greece (Kerkyra) in recent catalogues (Alonso-Zarazaga 2013, Alonso-Zarazaga et al. 2017) are erroneous and refer to Styphlidius corcyreus Reitter, 1884 of the subfamily Curculioninae. Adexius scrobipennis is widely distributed in central and southern Europe; it is also reported from Russian south European territory (ALONSO-ZARAZAGA et al. 2017), therefore its presence in the northern part of Caucasus Region is possible but it needs confirmation.

Distribution. Austria, Belgium, Bosnia and Herzegovina, Croatia, Czech Republic, France, Germany, Hungary, Italy, Luxembourg, Poland, Romania, Russia (central and southern territory), Slovakia, Slovenia, Spain, Switzerland, and Ukraine.

\section{Anchonidium Bedel, 1884}

(Figs 1b, 1d, 4a-f)

Anchonidium Bedel, 1884: 92 (original description). ReItTer (1913): 53 (key); Osella (1979): 348 (illustration of aedeagus, new records); Alonso-Zarazaga \& Lyal (1999): 195 (catalogue); Alonso-ZARAZAGa (2013): 496 (catalogue); Alonso-ZaraZAGa (2017): 490 (catalogue).

Type species. Styphlus unguicularis Aubé, 1850 by original designation.

Diagnosis. Body oval (Figs 1b, 1d), length 2.70-3.90 $\mathrm{mm}$; elytra in posterior part with erect setae. Head shorter than pronotum; eyes small, oval, invisible in dorsal view, situated at base of rostrum; rostrum carinate, densely punctate; scrobes visible dorsally; antennae (Fig. 4a) stout, scape short, not reaching anterior margin of eyes, funicule with 7 antennomeres, antennomeres II more than $1.4 \times$ as long as III. Pronotum lacking carinae or smooth median line, rugosely punctate, constricted before apex, postocular lobe absent, scutellum not visible. Elytra elongate, EL/EW ratio > 1.30, interstriae flat, striae with large, shallow punctures, apex of elytron rounded. Procoxae separated, mesocoxae widely separated. Ventrite I and II separated by straight suture, ventrite I clearly longer than II (Fig. 4b). Tarsomere III strongly bilobed, onychium long, at least as long as tarsomeres II and III combined. Median lobe of aedeagus symmetrical, with internal sclerites, parameres absent.

Distribution. Three species of Anchonidium are known; two are present in the Caucasus Region and another one is widespread in Europe. 


\section{Anchonidium caucasicum (Motschulsky, 1845)}

(Figs 1b, 4a-d)

Orthochaetes caucasicum Motschulsky, 1845: 100 (original description). Anchonidium caucasicum: SAVITSKY (2018): 105 (new combination).

Anchonidium corticeum Faust, 1886b: 32 (original description). AlonsoZARAZAGA (2013): 496 (synonymy).

Styphlus ulcerosus Aubé, 1850: 341 (original description).

Anchonidium ulcerosum: Osella (1979): 348 (illustration of aedeagus, distribution); SAVITSKY (2018): 103 (synonymy).

Type localities. Orthochaetes caucasicum: 'Montagnes du Caucase' [= Caucasus Mts.]; Anchonidium corticeum and Styphlus ulcerosus: 'environs de Batoum, en Iméritie' [= Georgia, Batumi env., ...].

Material examined. TURKEY: SAMSUN: $33 \mathrm{~km}$ SW of Samsun, $7 \mathrm{~km}$ SE of Kavak, $41^{\circ} 03^{\prime} 04^{\prime \prime} \mathrm{N}, 36^{\circ} 06^{\prime} 33^{\prime \prime} \mathrm{E}, 470$ m, 20.vii.2008, 13 spec., V. Assing lgt. (CPHP); $41 \mathrm{~km} \mathrm{~W}$ of Samsun, $27 \mathrm{~km} \mathrm{~S}$ of Bafra, $41^{\circ} 18^{\prime} 55^{\prime \prime} \mathrm{N}$, 35 50'51"E, $220 \mathrm{~m}, 21 . v i i .2008,1$ ô, 5 spec., V. Assing lgt. (CPHP).

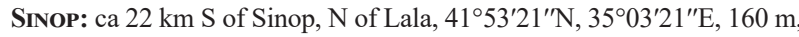
oak \& laurel forest, 31.iii.2009, 13 spec., V. Assing lgt. (CPHP). RUSSIA: WeSt CAucasus: $35 \mathrm{~km}$ NNE of Sochi, Babuk-Aul, in forest litter,

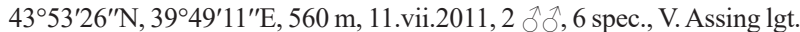
(CPHP). GEORGIA: IMERETI: Likani, 41,8428N, 43,3353E, 24.vii.2006, 1 , Chaladze lgt. (CPHP). Borjomi-Kharagauli NP, vill. Nunisi, sifting in mixed forest, $41^{\circ} 56^{\prime} 41.5^{\prime \prime} \mathrm{N}, 43^{\circ} 24^{\prime} 33.3^{\prime \prime} \mathrm{E}, 880 \mathrm{~m}$, numerous spec., P. Hlaváč lgt. (CPHP). KAKHETI: Tetritsklobi env., deciduous forest, sifting, 41.861638N, 45.861638E, 1300 m, 15.vii.2015, 1 , M. Kocian lgt. (CPHP). Mтskheta-Mtianeti: Sagurano Res., sifting, 29.v.2006, 1 q, Chaladze lgt. (CPHP). Southern OsSETIA: Džava [Java] env., v.[19]87, 3 spec., Rous lgt. (CJKH). Gufta [Didi Gupta] env., v.[19]87, 1 § 3 spec., Rous lgt. (CJKH). Ratacha Fl. [unknown location], v.[19]87, 1 spec., Rous lgt. (CJKH). SvanETI: valley of the Khuberi River, leaf litter sifting, 42.856190N, 42.039260E, 720 m, 4.vii.2015, 6 of 5 ㅇ․ M. Kocian lgt. (CPHP). Lakhamula vill., Madina River, sifting in mixed forest, 43.047559N, 42.456989E, 1100 m, 8.vii.2015, 1 §, M. Kocian lgt. (CPHP). Nadashi, Manshura valley, mixed forest, sifting, 43.055932N, 42.426047E, 1000 m, 8.vii.2015, $1 \lesssim 3$ ㅇ, M. Kocian lgt. (CPHP).

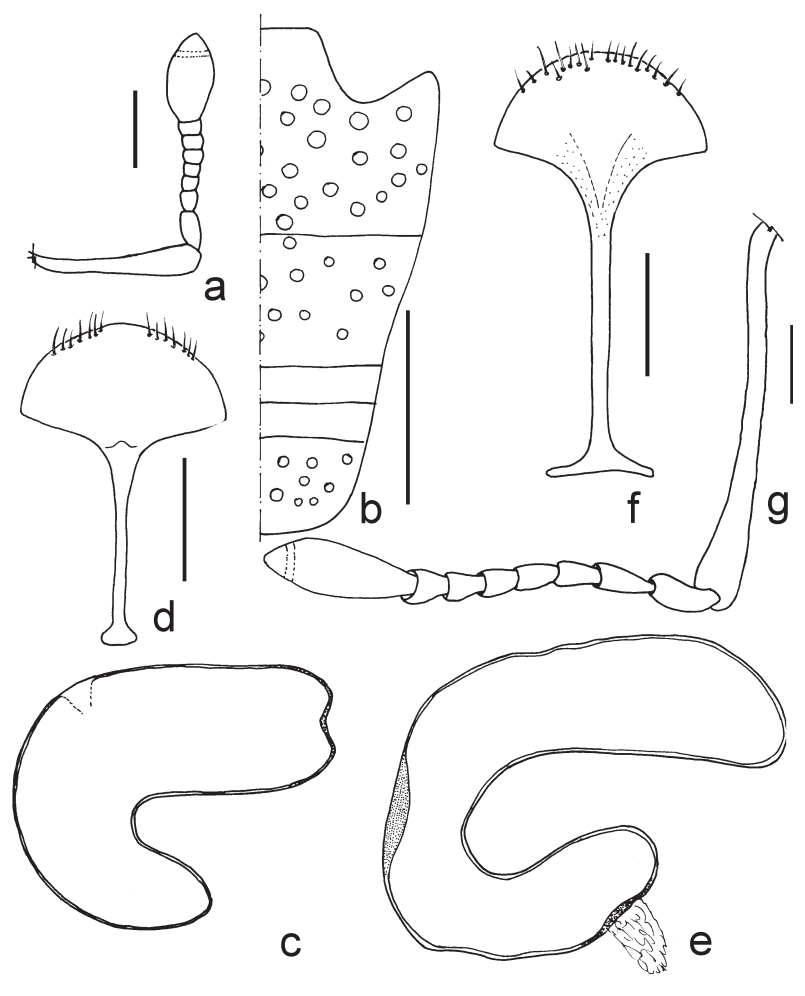

Fig. 4. Anchonidium caucasicum Motschulsky, 1845: a - antenna; b abdominal ventrites I-V; c-spermatheca; d-sternite VIII. Anchonidium perpensum Faust, 1886: e - spermatheca; f - sternite VIII. Aparopion costatum (Fåhraeus, 1843): g - antenna. Scale bars: $0.2 \mathrm{~mm}$.
Distribution. Bulgaria, Georgia, Romania, Russia (Caucasus), Turkey, Ukraine.

\section{Anchonidium perpensum Faust, 1886}

(Figs 1d, 4e-f)

Anchonidium perpensum Faust, 1886b: 32 (original description).

Type locality. 'Muchet' [probably Mccheta, Georgia].

Type material. HоLотуPE: + , 'Muchet, Balassog [h] / Type [p, red label] / Coll. J. Faust, Ankauf 1900 [p] / Staatl. Museum für Tierkunde, Dresden [p] / HOLOTYPE Anchonidium perpensum Faust, P. Hlaváč det., 2016 [p, red label]' (SMTD).

Redescription. Body convex (Fig. 1d), dark reddish-brown, legs and antennae of same colour. Length $3.78 \mathrm{~mm}$, maximum width of elytra $1.46 \mathrm{~mm}$. Eyes oval, clearly visible dorsally. Rostrum curved downwards, with three longitudinal carinae, median carina wide, lateral carinae narrow. Antennal scrobe deep, straight, reaching lower border before eyes. Antennae with scape about $1.25 \times$ as long as funicule; antennomeres II and III elongate and expanded towards apex, II about $1.4 \times$ as long as III, antennomeres IV-VI subequal, quadrate, shortest, antennomere VII $1.25 \times$ as long as VI and $0.85 \times$ as long as VIII, antennal club about $2.33 \times$ as long as antennomere II and about $1.90 \times$ as long as wide. Pronotum about $1.07 \times$ as long as wide, $1.46 \times$ as long as head, widest in middle, basal margin slightly convex, with closely arranged large punctures which become smaller, even evanescent in anterior third. Elytra long, subparallel-sided, $1.35 \times$ as long as wide, $1.81 \times$ as long as pronotum, with 9 striae of large punctures, distance between punctures less than diameter of puncture, elytral interstriae flat, with macrosetae in posterior part, humeri prominent. Female terminalia. Spermatheca (Fig. 4e), female sternite VIII (Fig. 4f), plate large, with evenly rounded apex bearing short setae.

Remarks. The original description of $A$. perpensum is based on a unique female specimen (thus holotype by monotypy) from Muchet in Caucasus (FAUst 1886b), which is most likely referring to Mccheta, ancient capital of Georgia situated close to Tbilisi. Despite many specimens of Anchonidium collected around Tbilisi, this species has never been recorded again since its original description. The study of the holotype revealed that this species is distinct from the widely distributed $A$. caucasicum. However, study of more specimens and particularly male would be desirable to confirm this hypothesis.

Differential diagnosis. Two Caucasian species can be separated using the key bellow.

Distribution. Georgia, so far known only from the type locality the exact location of which is not known for certain.

\section{Key to the species of Anchonidium from the Caucasus Region}

1. Head longer, PL/HL ratio $=1.35-1.40$; rostrum with dense setae; anterior median part of pronotum as densely punctate as on posterior two thirds; elytra evenly rounded; spermatheca with short corpus and cornu, corpus at apex with shallow excavation (Fig. 4c). A. caucasicum (Motschulsky, 1845) 
- Head shorter, PL/HL ratio = 1.46; rostrum with sparse setae; anterior median third of pronotum with smaller punctures than on posterior two thirds; surface close to anterior margin with very sparse punctation; elytra in anterior two thirds more parallel-sided; spermatheca with longer and slenderer corpus and cornu, corpus at apex rounded (Fig. 4e). ...... A. perpensum Faust, 1886

\section{Aparopion Hampe, 1861 \\ (Figs 1e, 4g)}

Aparopion Hampe, 1861: 68 (original description). ReITTER (1913): 53 (key); Alonso-ZarazaGa \& Lyal (1999): 196 (catalogue); AlonsoZARAZAGA (2013): 496 (catalogue); Alonso-ZAraZAGA (2017): 491 (catalogue).

Type species. Aparopion costatum Hampe, 1861 (= Trachodes costatus Fåhraeus, 1843) by monotypy.

Diagnosis. Body slightly oval, length $3.7-5.8 \mathrm{~mm}$. Elytra and pronotum lacking erect setae, head about as long as pronotum. Eyes large, oval, clearly visible in dorsal view, situated at base of rostrum. Rostrum lacking carinae, densely punctate, scrobes visible dorsally. Antennae (Fig. $4 \mathrm{~g}$ ) slender, scape long, reaching anterior margin of eyes, funicule with 7 antennomeres, antennomeres II and III approx. of same length, all antennomeres elongate. Pronotum lacking carinae or smooth median line, rugosely punctate, constricted before apex, postocular lobe absent, scutellum not visible. Elytra wide, EL/EW ratio $<1.25$, interstriae elevated, granulate, striae composed of single row of small deep punctures, apex of each elytron with well-defined preapical constriction. Procoxae separated, mesocoxae widely separated, ventrite I and II separated by straight suture, ventrite I clearly longer than II. Tarsomere III strongly bilobed, onychium long, at least as long as tarsomeres II and III together. Median lobe of aedeagus asymmetrical, with internal sclerites, parameres absent.

Remarks. The genus was recently revised (ZUPPA \& OsELla 1999) and four species were recognized, A. chevrolati (Jacquelin du Val, 1855) and A. suturidens Reitter, 1891 from France and Italy, the newly described species A. numidicum Zuppa \& Osella, 1999 from Algeria, and relatively widespread $A$. costatum.

\section{Aparopion costatum (Fåhraeus, 1843)}

(Figs 1e, 4g)

Trachodes costatum Fåhraeus, 1843: 409 (original description).

Aparopion costatum: ZuPPA \& OSELLA (1999): 9 (redescription, all previous relevant references listed).

Type locality. 'Passau Bavariae' [= Germany, Bavaria, Passau]. Material examined. GEORGIA: IMERETI: Borjomi-Kharagauli NP, vill. Nunisi, SAMPLE 3, sifting in mixed forest, $41^{\circ} 56^{\prime} 41.5^{\prime \prime} \mathrm{N}$,

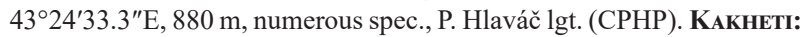
Tetritsklebi env., deciduous forest, sifting, 41.861638N, 45.337633E, 1300 m, 15.vii.2015, 1 spec., M. Kocian lgt. (CPHP); Pshaveli env., above Lechuri, deciduous, forest sifting, 42.147491N, 45.413303E, $580 \mathrm{~m}$, 14.vii.2015, 2 spec., Z. Švec lgt. (CPHP). SvanETI: Valley of the Khuberi River, leaf litter sifting, 42.856190N, 42.039260E, 720 m, 4.vii.2015, 1 9, 2 spec., 11.vii.2015, 1 spec., M. Kocian lgt. (CPHP). NORTH MACEDONIA: Bistra Mts., Mavrovo env., valley of Radika River, 1515 m, 17.vi.2011, 1 spec., P. Hlaváč lgt. (CPHP). RUSSIA: WESTERN

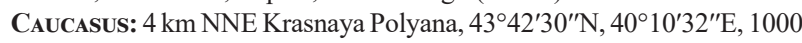
m, 18.vii.2011, 2 spec., V. Assing (PHPC).
Distribution. Species widely distributed in central and southern Europe but absent in western Europe, the Iberian Peninsula and Italy.So far reported from Albania, Azerbaijan, Bosnia and Herzegovina, Bulgaria, Croatia, Georgia, Germany, Greece, Hungary, North Macedonia, Romania, Serbia, Russia (southern European territory), Turkey, and Ukraine.

\section{Caulomorphus Faust, 1886}

(Figs 1c, 5a-f, 6a-c, 7a-e)

Caulomorphus Faust, 1886a: 28 (original description). ReITTER (1913): 53 (key); Osella (1970): 361 (revision); Osella (1976): 93 (new species, key); Alonso-ZARAZAGA \& Lyal (1999): 195 (catalogue); Osella et al. (2003): 690 (new species, new records, key); AlonsoZaraZAGA (2013): 488 (catalogue); Alonso-ZaraZAGA (2017): 481 (catalogue); Morrone \& Hlavíč (2017): 60 (catalogue).

Type species. Styphlus lederi Chevrolat, 1880 by original designation.

Diagnosis. Body parallel-sided, length 3.0-4.2 mm. Elytra and pronotum lacking erect setae, head slightly longer than pronotum. Eyes reduced to single ommatidium, situated at base of rostrum. Rostrum carinate, densely punctate, scrobes visible dorsally. Antennae slender, scape short, not reaching anterior margin of eyes, funicule with 7 antennomeres, antennomeres II more than $1.4 \times$ as long as III. Pronotum lacking carinae or smooth median line, rugosely punctate, simply convergent to apex, postocular lobe absent, scutellum not visible. Elytra elongate, EL/EW ratio $>1.30$, interstriae flat, striae with large punctures, apex of each elytron rounded. Procoxae separated, mesocoxae widely separated, ventrite I and II (Fig. 6h) separated by sinuate suture, ventrite I clearly longer than II, tarsomere III strongly bilobed, onychium long, at least as long as tarsomeres II and III together. Median lobe of aedeagus symmetrical, with internal sclerites, parameres absent.

Biology. Caulomorphus species are collected by sifting litter in deciduous forest, one female was collected in Armenia by sifting dead wood.

Distribution. Armenia, Azerbaijan, Georgia, Iran, and Turkey.

Remarks. The genus Caulomorphus was revised by OsElla (1970). After that, only three new species were described (OsElla 1976, 1977; Osella et al. 2003). Catalogue of all species was provided by MORONNE \& HLAVÁč (2017). Currently the genus contains twelve species including the new one described in this paper.

Females of Caulomorphus are not possible to be reasonably identified if they are not collected together with males; the study of the aedeagus is inevitable for the correct species identification.

\section{Caulomorphus besucheti Osella, 1970 (Figs $5 \mathrm{a}-\mathrm{c}$ )}

Caulomorphus besucheti Osella, 1970: 366 (original description). OsELlA et al. (2003): 689, 691 (key), 692 (key).

Type locality. Turkey, Trabzon, Yomra.

Material examined. TURKEY: SINOP: ca $22 \mathrm{~km}$ of S Sinop, N of Lala, 41 ${ }^{\circ} 53^{\prime} 21^{\prime \prime} \mathrm{N}, 35^{\circ} 03^{\prime} 21^{\prime \prime} \mathrm{E}, 160 \mathrm{~m}$, oak \& laurel forest, 31.iii.2009, 4 ठे 1 +, 6 spec., V. Assing and P. Wunderle lgt. (ZMHB, CPHP);

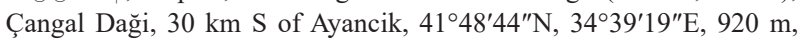




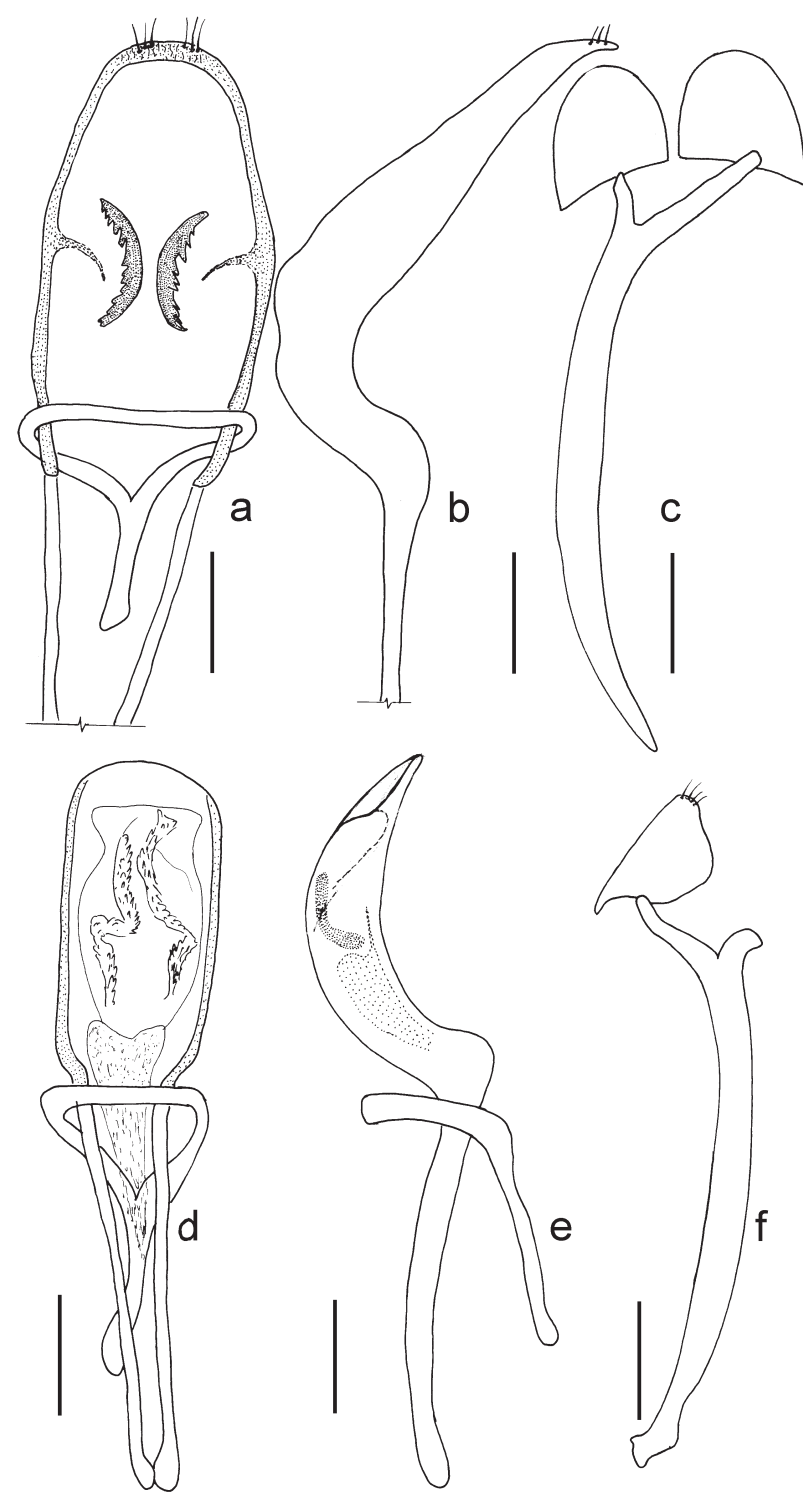

Fig. 5. Caulomorphus besucheti Osella, 1970: a-aedeagus, dorsal view; b - aedeagus, lateral view; c - sternite IX and hemisternites; Caulomorphus talyschensis Reitter, 1897: $\mathrm{d}$-aedeagus, dorsal view; $\mathrm{e}$-aedeagus, lateral view; $\mathrm{f}-$ sternite IX and hemisternite. Scale bars: $0.2 \mathrm{~mm}$.

beech forest, 1.iv.2009. $2 \lesssim 1$ †, V. Assing lgt. (ZMHB, CPHP). GEORGIA: ADJARA: Mtirala NP, Chakvistavi, 25.-26.vii.2014, 1 , O. Konvička lgt. (CJKH); Mtirala NP, above Chakvistavi, sifting in forest, 41.654720N, 41.873877E, 1100 m, 30.v.2019, 4 ๙ 1 ․, M. Kocian lgt. (CPHP). IMERETI: Borjomi-Kharagauli NP, vill. Nunisi, sifting in mixed forest, $41^{\circ} 56^{\prime} 41.5^{\prime \prime} \mathrm{N}, 43^{\circ} 24^{\prime} 33.3^{\prime \prime} \mathrm{E}, 880 \mathrm{~m}, 4 \hat{\jmath} \jmath, 2$ spec., P. Hlaváč lgt. (CPHP). MTSKheta-Mtianeti: Tbilisi NP, above Buriani, sifting in forest, 41.887274N, 44.876954E, 950 m, 28.v.2019, 2 ふै, M. Kocian lgt. (CPHP).

Redescription. Body convex. Length 3.30-4.20 mm, maximum width of elytra $1.10-1.35 \mathrm{~mm}$. Head and pronotum matt, elytra light shiny, reddish-brown, legs and antennae of same colour, sometimes elytra and antennae more reddish. Rostrum curved downwards, with three longitudinal carinae, with short apical setae, scrobe deep, straight, not visible in dorsal view. Antennae long, with dense pubescence, scape elongately pedunculate at base, about 1.15 $1.20 \times$ as long as funicule, funicule with 7 antennomeres; antennomeres II and III elongate and expanded towards apex, II about $1.80-2.00 \times$ as long as III, antennomeres IV-VI subequal, about as long as wide, shortest, about 0.7 $\times$ of length of antennomere III, antennomere VII $1.2 \times$ as long as VI and $0.85 \times$ as long as VIII, antennal club about twice as long as antennomere II and about $1.65 \times$ as long as wide. Pronotum 1.00-1.05 $\times$ as long as wide, $1.10-1.20$ $\times$ as long as head, widest in middle, basal margin straight, with closely arranged large and subequal punctures, with thin but well-defined median carina. Elytra long, subparallel-sided, $1.65-1.75 \times$ as long as wide, $2.20-2.30 \times$ as long as pronotum, with about ten striae composed of punctures of equal size, distance between punctures approximately as wide as diameter of puncture, elytral interstriae slightly elevated, with even, short, golden setae, humeri prominent. Prosternum rugosely sculptured, with uneven large punctures. Procoxae separated by narrow isthmus. Mesoventrite about as long as metaventrite, mesoventrite shagreened, with even, sparse, small punctures bearing microseta, with some larger punctures on short mesoventral process, mesocoxae separated, isthmus about as wide as half of coxa. Metaventrite with large, shallow, closely arranged uneven punctures and golden setation, metacoxae strongly separated by large, convex process of ventrite I. Ventrite I longer than II, both punctate and with golden setation. Male terminalia. Aedeagus (Figs 5a-b) wide, flattened dorsally, laterally curved, with acuminate apex, male sternite IX (Fig. 5c) curved, asymmetrical, hemisternite round at apex, base slightly concave, lacking apical setae.

Distribution. Georgia (Adjara, Imereti, Mtskheta-Mtianeti) and Turkey (Aydin, Artvin, Sinop, Rize).

\section{Caulomorphus kociani sp. nov.} (Figs 1c, 6a-c, 7a-e)

Type locality. Armenia, Goris, 39.516611N, 46.322847E, $1700 \mathrm{~m}$ a.s.1. Type material. HoLOTYPE: Oे, 'ARMENIA, Goris, E slope, deciduous forest, leaf litter sifting, $1700 \mathrm{~m}, 25 . \mathrm{V} .2015,39.516611 \mathrm{~N} 46.322847 \mathrm{E}$,

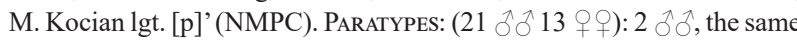
data as holotype (CPHP); $3 \hat{\partial} 1 \hat{0}$, 'ARMENIA, Tatev env., Vorotan Valley, sifting in macchia, $1300 \mathrm{~m}, 24$.V.2015, 39.394394N 46.247672E, M. Kocian lgt. [p]' (CPHP); 1 2 $\uparrow$, 'ARMENIA, Syunik r., $5 \mathrm{~km} \mathrm{~N}$ of Shurnukh, 07.06.2015, F. Pavel lgt. [p] $/ 39^{\circ} 24^{\prime} 15.7^{\prime \prime N}, 046^{\circ} 24^{\prime} 37.8^{\prime \prime} \mathrm{E}$ [p]' (CJKH); 1 , 'ARMENIA - Syunik pr., Davit Bek env., N of Karmrakar, 7.6.2017, lgt. Jan Pelikán / 39 $19^{\circ} 00^{\prime \prime} \mathrm{N}, 46^{\circ} 28^{\prime} 16^{\prime \prime} \mathrm{E}, 1474 \mathrm{~m}$, kořeny [roots] Corylus. [p]' (CJPH); 8 ô, 3 spec., 'Armenia, 25 km S Kapan, Gomarants Ps., 3901'32"N, 46 $21^{\prime} 59^{\prime \prime} \mathrm{E}, 2190 \mathrm{~m}$, oak forest, 7.VII.2016, V. Assing [p]' (BMNH, CPHP, OUMNH, ZMHB, CLFC); 1 ô, 'Armenia [33]-WSW, Kapan, above Shishkert, 39 $03^{\prime} 48^{\prime \prime} \mathrm{N}, 46^{\circ} 21^{\prime} 36^{\prime \prime} \mathrm{E}, 2040 \mathrm{~m}$, forest litter sift., 12.vii.2018, V. Assing [p]' (ZMHB); 2 o 3 q 9 , 'Armenia [27]-WSW, Kapan, W Karajan, 39 $09^{\prime} 22^{\prime \prime} \mathrm{N}, 46^{\circ} 06^{\prime} 13^{\prime \prime} \mathrm{E}, 2050 \mathrm{~m}$, mixed forest, 10.VII.2018, V. Assing [p]' (ZMHB); 1 ' 2 우, 'Armenia [38]-20 km SW Sisian Darbas, 39² $25^{\prime} 55^{\prime \prime} \mathrm{N}, 46^{\circ} 06^{\prime} 57^{\prime \prime} \mathrm{E}, 1680 \mathrm{~m}$, forest margin, 16.VII.2018, V. Assing [p]' (ZMHB); 2 ○े 2 우, 'Armenia [28]- ca $30 \mathrm{~km} \mathrm{~W}$ Kapan, $39^{\circ} 15^{\prime} 13^{\prime \prime} \mathrm{N}, 46^{\circ} 04^{\prime} 16^{\prime \prime} \mathrm{E}, 2040 \mathrm{~m}$, forest margin, 11.VII.2018, V. Assing [p]' (ZMHB, PCLF).

Description. Body (Fig. 1c) convex. Length 3.10-4.10 $\mathrm{mm}$, maximum width of elytra $1.00-1.20 \mathrm{~mm}$. Head and pronotum shiny, whole body, antennae and legs unicoloured reddish-brown, elytra with dense setae. Rostrum curved downwards, with five longitudinal carinae, with short apical setae, scrobe deep, straight, not visible in dorsal view. Antennae (Fig. 7a) long, with dense pubes- 


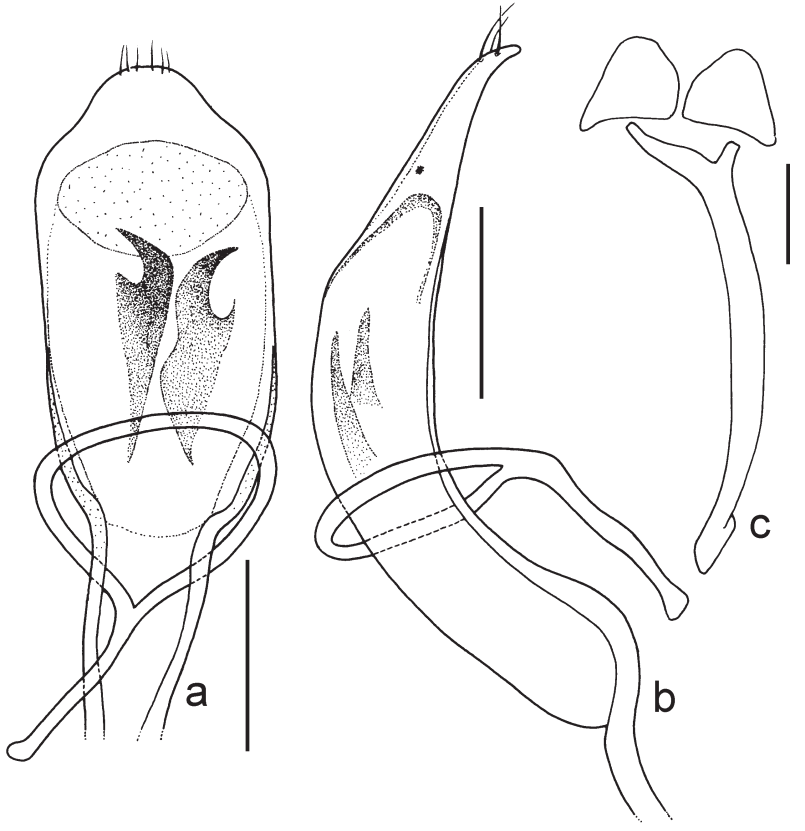

Fig. 6. Caulomorphus kociani sp. nov. a-aedeagus, dorsal view; b - aedeagus, lateral view; c - sternite IX and hemisternites. Scale bars: $0.2 \mathrm{~mm}$.

cence, scape thin and parallel-sided at base and expanded towards apex, about $1.10 \times$ as long as funicule, funicule with 7 antennomeres; antennomeres II and III elongate and expanded towards apex, antennomere II 1.40-1.60× as long as III, antennomeres IV-VI subequal, about as long as wide, shortest, about $0.6 \times$ as long as antennomere III, antennomere VII $1.25 \times$ as long as VI and subequal to VIII, antennal club about twice as long as antennomere II and about $1.75 \times$ as long as wide. Pronotum $0.90-1.05 \times$ as long as wide, $1.00-1.05 \times$ as long as head, widest in middle, basal margin straight, with closely arranged large and subequal punctures, with thin but well-defined median carina. Prosternum rugosely sculptured, with uneven large punctures, hypomerae fused with median part of prosternum; procoxae touching, isthmus interrupted. Mesoventrite evenly, densely punctate, in middle about as long as metaventrite. Metaventrite with even and large puctures, punctures much larger than those on mesoventrite. Mesocoxae well-separated, width of isthmus about $1 / 3$ of mesocoxa diameter, posterior meso- and anterior metaventral processes truncate. Metacoxae widely separated by large, posterior metaventral process with well-defined median notch. Ventrite I about $1.3 \times$ longer than II, both punctate, with golden setation (Fig. 7b). Elytra long, subparallel-sided, on sides slightly rounded in apical third, 1.40-1.75× as long as wide, $2.15-2.30 \times$ as long as pronotum, with eight striae composed of large punctures of equal diameter, distance between each two punctures within row slightly less than diameter of puncture, elytral interstriae elevated, with even micropunctures bearing short, golden setae. Male terminalia. Aedeagus (Figs 6a-b) wide, flattened dorsally, before apex narrowed, laterally slightly curved, with acuminate apex, with two subequal sclerites, male sternite IX (Fig. 6c) curved, asymmetrical, hemisternite

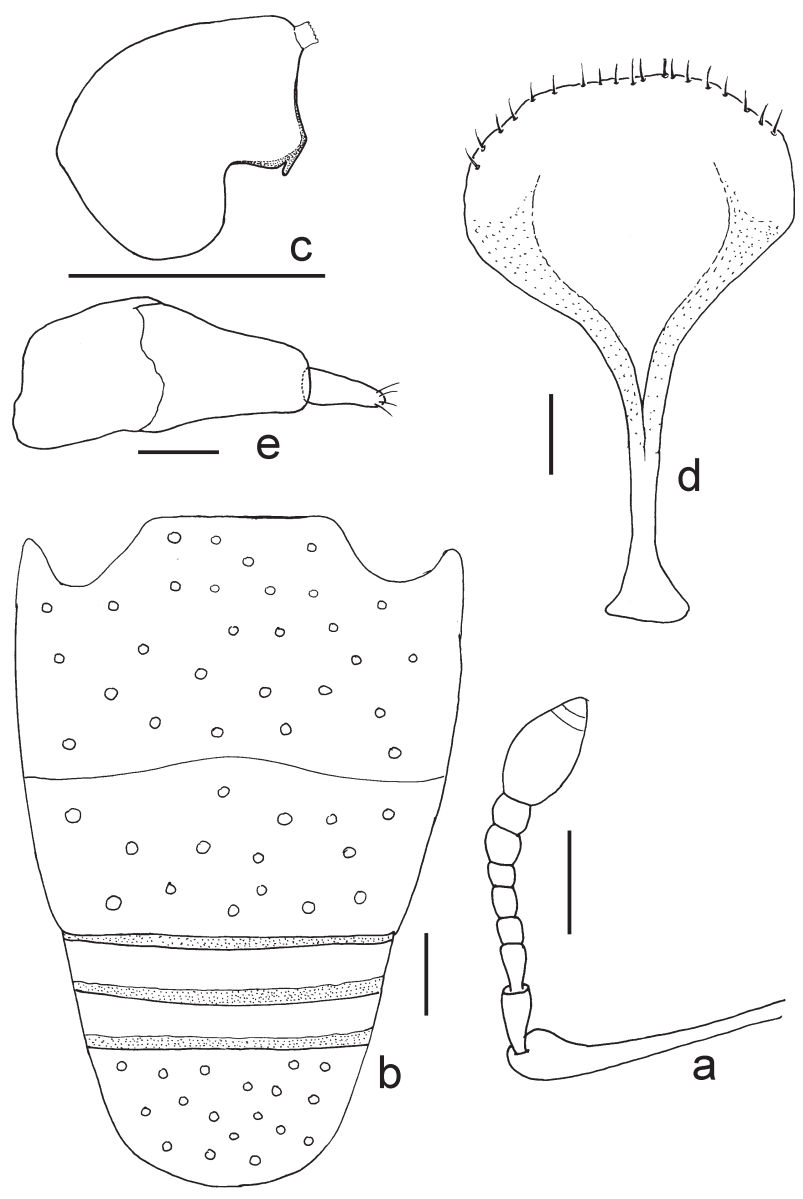

Fig. 7. Caulomorphus kociani sp. nov., a - antenna; b - abdominal ventrites I-V; c - spermatheca; d - sternite VIII; e - gonocoxite. Scale bars: $0.2 \mathrm{~mm}$.

rounded at apex, base slightly concave, lacking apical setae. Female terminalia. Spermatheca (Fig. 7c), female sternite VIII (Fig. 7c), gonocoxite (Fig. 7d).

Differential diagnosis. Caulomorphus kociani sp. nov. and the most similar species $C$. besucheti are readily separated from its congeners by sharing the subparallel-sided elytra, symmetrical, wide, flattened and laterally curved aedeagus and pronotum lacking median carina, however the new species differs from $C$. besucheti in different shape and different internal structures of the aedeagus (see Figs 5a-b). Etymology. Patronymic, named after Matúš Kocian (Prague, Czech Republic), specialist on Staphylinidae and the collector of part of the type series.

Distribution. Armenia.

\section{Caulomorphus talyschensis Reitter, 1897} (Figs 5d-f)

Caulomorphus talyschensis Reitter, 1897: 126 (original description). Reitter (1911): 159 (key); Osella (1970): 377 (redescription); Osella et al. (2003): 691 (key), 693 (key).

Type locality. ‘bei Lenkoran' [= Azerbaijan, near Lenkoran]. Material examined. AZERBAIJAN: Astara, Istisu W Astara, $100 \mathrm{~m}$, 2.-6.vi.1996, 1 \% 1 , W. Schawaller lgt. (SMNS, CPHP).

Redescription. Body convex. Length $3.60-3.70 \mathrm{~mm}$, maximum width of elytra $1.10-1.20 \mathrm{~mm}$. Head and 
pronotum shiny, body and legs pitchy-brown, antennae slightly lighter, elytra with short golden setae. Rostrum curved downwards, with five longitudinal carinae, with short apical setae, scrobe deep, straight, not visible in dorsal view. Antennae long, with dense pubescence, scape longly pedunculate at base, about $1.20 \times$ as long as funicule, funicule with 7 antennomeres; antennomeres II and III elongate and expanded to apex, II about $1.7 \times$ as long as III, antennomeres IV and V subequal, V $1.25 \times$ as long as $\mathrm{IV}$, antennomeres V, VII and VIII subequal, antennal club about $1.80-1.85 \times$ as long as antennomere II and about $1.80 \times$ as long as wide. Pronotum $1.00-1.05 \times$ as long as wide, $1.05-1.15 \times$ as long as head, widest in middle, basal margin straight, with closely arranged, large and almost equal punctures, lacking median carina. Prosternum rugosely sculptured, with uneven large punctures. Procoxae separated by narrow isthmus. Mesoventrite about as long as metaventrite, mesoventrite shiny, with even small punctures bearing microseta, with some large punctures on short mesoventral process, mesocoxae separated, isthmus about as wide as half of coxa. Metaventrite with large, shallow, almost confluent punctures and golden setation, metacoxae strongly separated by large, triangular process. Ventrite I longer than II, similarly punctate. Elytra long, subparallel-sided, $1.55-1.60 \times$ as long as wide, about $2.10 \times$ as long as pronotum, with eight striae composed of large punctures of equal diameter, distance between each two punctures within row slightly less than diameter of puncture, elytral interstriae elevated, with even micropunctures bearing short, golden setae, humeri prominent. Male terminalia. Aedeagus (Figs 5d-e) slender, apical lobe parallel-sided, flattened dorsally, rounded at apex, laterally slightly curved, with sharply acuminate apex, with two subequal sclerites, male sternite IX (Fig. 5f) curved, asymmetrical, hemisternite with four short apical setae.

Distribution. So far, the species is known only from costal area of the Caspian Sea in Azerbaijan.

\section{Key to males of Caulomorphus from the Caucasus Region (modified after OsELla et al. 2003)}

1 Elytra oblong-oval, widest in middle.

- Elytra subparallel-sided. ............................................. 2 curved. .... 3

- Aedeagus narrow, parallel-sided, laterally strongly curved (Fig. 5d).

\section{6}

3 Aedeagus asymmetrical, pronotum lacking median carina.

C. giocoae Osella, 1970

- Aedeagus symmetrical, pronotum with or without median carina.

4 Pronotum with median carina, sometimes weak but always clearly visible. ......... C. lederi (Chevrolat, 1880)

- Pronotum lacking median carina.

5 Aedeagus with two dentate sclerites, apex oval (Fig. $5 a)$. C. besucheti Osella, 1970

- Aedeagus with two pointed sclerites, apex slightly constricted (Fig. 6a). C. kociani sp. nov.
6 Elytra with well-defined half-recumbent setae.

C. talyschensis Reitter, 1897

- Elytra with short recumbent setae.

C. amaseianus Osella, 1970

\section{Pseudaparopion Borovec, Osella \& Zuppa, 2002 (Fig. 1f)}

Pseudaparopion Borovec, Osella \& Zuppa, 2002: 870 (original description). Alonso-ZaraZaGa (2013): 497 (catalogue); Alonso-ZaraZAGa (2017): 491 (catalogue).

Type species. Aparopion aequale Reitter, 1883 by original designation.

Diagnosis. Body oval, length $3.8-5.1 \mathrm{~mm}$, elytra and pronotum lacking erect setae, head longer than pronotum, eyes large, oval, clearly visible in dorsal view, situated at base of rostrum, rostrum lacking carinae, densely punctate, punctures small, scrobes visible dorsally, antennae inserted subapically, slender, scape long, reaching anterior margin of eyes, funicule with 7 antennomeres, antennomeres II and III of about same length. Pronotum simply convergent in anterior part, lacking carinae or smooth median line, rugosely punctate, postocular lobe absent, scutellum not visible. Elytra wide, EL/EW ratio $<1.25$, with elevated granulate interstriae, striae with punctures, confluent with interstriae, with fine setae on whole surface, apex of elytra sharp, lacking constriction, procoxae separated, mesocoxae widely separated, ventrite I and II separated by suture, ventrite I about as long as II, tarsomere III strongly bilobed, onychium long, clearly longer than tarsomeres II and III together, median lobe of aedeagus symmetrical, tegmen lacking parameres.

Remarks. The genus has been proposed for two species, Aparopion aequale Reitter, 1883 from Azerbaijan (Lenkoran), which was found not to be congeneric with the other species of Aparopion based on the structure of elytra that are not carinate and lack tubercules, and on a different shape of female genitalia (ZuPPA \& OsELla 1999), and for a new, closely related species, Pseudaparopion kadleci Borovec, Osella \& Zuppa, 2002 from the Mazandaran Province of Iran.

\section{List of Typoderini taxa from the Caucasus Region}

[Adexius Schönherr, 1834]

[A. scrobipennis Gyllenhal, 1834] widespread in Europe, occurrence in the Caucasus probable

\section{Anchonidium Bedel, 1884}

A. perpensum Faust, $1886 \quad$ Georgia

A. caucasicum Motschulsky, 1845 Croatia to the Caucasus

(S Russia, Turkey)

\section{Aparopion Hampe, 1861}

A. costatum (Fåhraeus, 1843)

widespread: $\mathrm{C}$ and $\mathrm{S}$ Europe to the Caucasus (Azerbaijan, Georgia, Russia and Turkey) 


\section{Caulomorphus Faust, 1886}

C. amaseianus Osella, 1970

C. besucheti Osella, 1970

C. giocoae Osella, 1970

C. kociani sp. nov.

C. lederi (Chevrolat, 1880)

C. muelleri Reitter, 1911

C. talyschensis Reitter, 1897

Georgia and Turkey

(Amasya)

Georgia (Adjaria) and

Turkey (Artvin, Ordu,

Trabzon)

Turkey (Artvin)

Armenia

Georgia

Georgia (Svaneti)

Azerbaijan(Lenkoran)

Pseudaparopion Borovec, Osella \& Zuppa, 2002

P. aequale (Reitter, 1884)

Azerbaijan (Talysh Mts.)

\section{Acknowledgements}

I thank Matúš Kocian (Prague, Czech Republic) and Volker Assing (Hannover, Germany), collectors of most of the studied material as well as Joachim Willers and Bernd Jaeger who made available the material deposited in ZMHB. I also thank Jon Cooter (OUMNH) for reading and correcting the manuscript and Oto Nakládal (Prague, Czech Republic) for arranging all the figures. Lech Borowiec (Wroclaw, Poland) and Kiril Makarov (Moscow, Russia) are acknowledged for providing excellent photographs of the habitus of Adexius scrobipennis and Anchonidium caucasicum, respectively. Petr Baňař (Brno, Czech Republic) prepared the photographs of Aparopion costatum and Psedaparopion kadleci, Pavel Krásenský (Chomutov, Czech Republic) took the photograph of Caulomorphus kociani. The work was supported by the Ministry of Culture of the Czech Republic (DKRVO 2019-2023/5.I.b, National Museum, 00023272).

\section{References}

ALONSO-ZARAZAGA M. A. 2013: Molytinae. Pp. 475-497. In: LÖBL I \& SMETANAA(eds): Catalogue of Palaearctic Coleoptera, Volume 8, Curculionoidea II. Brill, Leiden, $700 \mathrm{pp}$.

ALONSO-ZARAZAGA M. A. 2017: Molytinae. Pp. 456-492. In: ALONSO-ZARAZAGA M. A., BARRIOS H., BOROVEC R., BOUCHARD P., CALDARA R., COLONNELLI E., GÜLTEKIN L., HLAVÁČ P., KOROTYAEV B., LYAL C. H. C., MACHADO A., MEREGALLI M., PIEROTTI H., REN L., SÁNCHEZ-RUIZ M., SFORZI A., SILFVERBERG H., SKUHROVEC J., TRÝZNA M., VELÁZQUEZ DE CASTRO A. J. \& YUNAKOV N. N. 2017: Cooperative catalogue of Palaearctic Coleoptera Curculionoidea. Monografías electrónicas S.E.A., Vol. 8. Sociedad Entomológica Aragonesa, Zaragoza, 729 pp.

ALONSO-ZARAZAGA M. A. \& LYAL C. H. C. 1999: A World Catalogue of Families and Genera of Curculionoidea (Excepting Scolytidae and Platypodidae). Entomopraxis, Barcelona, 315 pp.

BOROVEC R., OSELLA G. \& ZUPPAA. M. 2002: Psedaparopion, new genus of Curculionidae from southern Caspic Region (Coleoptera, Curculionidae, Molytinae). Revue Suisse de Zoologie 109: 869-877.

FAUST J. 1886a: Bemerkungen zu einigen europäischen CurculionidenGattungen. Entomologische Zeitung (Stettin) 47: 22-31.

FAUST J. 1886b: Beschreibung neuer Anchonidium-Arten aus dem Caucasus. Entomologische Zeitung (Stettin) 47: 32-33.

GREBENNIKOV V. V. 2017: Phylogeography and sister group of Lupangus, a new genus for three new flightless allopatric forest litter weevil endemic to the Eastern Arc Mountains, Tanzania (Coleoptera: Curculionidae, Molytinae). Fragmenta Entomologica 49: 37-55.
LYAL C. H. C. 2014: Molytinae Schoenherr, 1823. Pp. 529-570. In: LESCHEN R. A. B. \& BEUTEL R. G. (eds.): Handbook of Zoology, Arthropoda: Insecta: Coleoptera. Volume 3: Morphology and Systematics (Phytophaga). Walter de Gruyter, Berlin-Boston, 675 pp.

MORONNE J. \& HLAVÁČ P. 2016: Checklist of the micro- and anophthalmic soil-dwelling weevils of the world (Coleoptera: Curculionidae). Zootaxa 4239: 1-102.

MOTSCHULSKY V. 1845: Remarques sur la collection de Coléoptères russes de Victor de Motschulsky. Bulletin de la Société Impériale des Naturalistes de Moscou 18: 3-127, 549 (erratum) + pls. 1-3.

OBERPRIELER R. G., ANDERSON R. S. \& MARVALDI A. E. 2014: Curculionoidea Latreille, 1802: Introduction, Phylogeny. Pp. 285-300. In: LESCHEN R. A. B. \& BEUTEL R. G. (eds.): Handbook of Zoology, Arthropoda: Insecta; Coleoptera, Beetles. Vol. 3. Morphology and systematics (Phytophaga). Walter de Gruyter, Berlin-Boston, 675 pp.

OSELLA G. 1970: Revisione del genere Caulomorphus Faust e descrizione di cinque nuove specie delle regioni montuose dela Turchia lungo il Mar Nero. Memorie del Museo Civico di Storia Naturale di Verona 17: 359-395.

OSELLA G. 1976: Descrizione di una nuova specie Caulomorphus Faust della Persia (Coleoptera, Curculionidae). Verhandlungen der Naturforschenden Gesellschaft in Basel 85: 92-94.

OSELLA G. 1977: Contributo alla conoscenza della Curculionidofauna endogea dell'Iran Settentrionale. (XIV. Contributo alla conoscenza della curculionidofauna endogea). Revue Suisse de Zoologie 84: 145-171.

OSELLA G. 1979: Un nuovo genere di Curculionidae (Pseudoanchonidium m.: Col. Curc.: Hylobiinae) del vicino oriente e note sulla distribuzione di Anchonidium ulcerosum (Aube) (XXI. Contributo alla conoscenza della curculionidofauna endogea). Revue Suisse de Zoologie 86: 339-349.

OSELLA G., DI MARCO C. \& ZUPPA A. M. 2003: Un nuovo Caulomorphus Faust, 1886 d'Anatolia (Coleoptera, Curculionidae, Molytinae). Revue Suisse de Zoologie 110: 685-693.

REITTER E. 1911: Übersicht der Arten der Curculioniden-Gattung Caulomorphus Faust. Wiener Entomologische Zeitung 30: 159.

REITTER E. 1913: Bestimmungs-Schlüssel der mir bekannten europäischen Gattungen der Curculionidae, mit Einschluss der mir bekannten Gattungen aus dem palaearktischen Gebiete. Verhandlungen des Naturforschenden Vereines in Brünn 51 [1912]: 1-90.

RIEDEL A., TAZLER R., PONS J., SUHARDJONO Y. R. \& BALKE M. 2016: Large-scale molecular phylogeny of Cryptorhynchinae (Coleoptera, Curculionidae) from multiple genes suggests American origin and later Australian radiation. Systematic Entomology 41: 492-503.

SAVITSKY Y. V. 2018: (Little-known weevil taxa (Coleoptera, Curculionidae) described by V. I. Motschulsky from the Caucasus.) Entomologicheskoe Obozrenie 47: 102-109 (in Russian, English summary).

ZHERIKHIN V. V. 1987: Curculionidae from the Nepal Himalayas. Part 1. Molytinae (Insecta: Coleoptera). Stuttgarter Beiträge zur Naturkunde, Serie A (Biologie) 411: 1-43.

ZUPPA A. M. \& OSELLA G. 1999: Revisione del genere Aparopion Hampe, 1861 (Coleoptera, Curculionidae, Molytinae). Bollettino del Museo Civico di Storia Naturale di Verona, Botanica Zoologia 23: $1-49$.

Editorial note. This paper was originally published on-line on $3^{\text {rd }} \mathrm{De}-$ cember 2020 but included mistakes in the legend of Figure 1 and in references to figures in the text. These mistakes would cause an incorrect understanding of the species treated. To prevent confusion and to comply the requirements of ICZN on on-line publishing, we corrected the legend of Fig. 1 and the incorrect references in the text in the current version, updated the date of publication in ZooBank to $4^{\text {th }}$ December 2020 , and replaced the original file in Biotaxa for the current one. Therefore, $4^{\text {th }}$ December 2020 must be understood as the publication date of the paper for the purpose of zoological nomenclature. 